\title{
STATIC LOAD TEST ON INSTRUMENTED PILE - FIELD DATA AND NUMERICAL SIMULATIONS
}

\author{
ADAM KRASIŃSKI, MATEUSZ WISZNIEWSKI \\ Department of Geotechnics, Geology and Marine Civil Engineering, Faculty of Civil and Environmental Engineering, \\ Gdansk University of Technology, ul. Gabriela Narutowicza 11/12, 80-233 Gdańsk, Poland, \\ e-mail: akra@pg.gda.pl, mateusz.wiszniewski@pg.gda.pl
}

\begin{abstract}
Static load tests on foundation piles are generally carried out in order to determine load - the displacement characteristic of the pile head. For standard (basic) engineering practices this type of test usually provides enough information. However, the knowledge of force distribution along the pile core and its division into the friction along the shaft and the resistance under the base can be very useful. Such information can be obtained by strain gage pile instrumentation [1]. Significant investigations have been completed on this technology, proving its utility and correctness [8], [10], [12]. The results of static tests on instrumented piles are not easy to interpret. There are many factors and processes affecting the final outcome. In order to understand better the whole testing process and soil-structure behavior some investigations and numerical analyses were done. In the paper, real data from a field load test on instrumented piles is discussed and compared with numerical simulation of such a test in similar conditions. Differences and difficulties in the results interpretation with their possible reasons are discussed. Moreover, the authors used their own analytical solution for more reliable determination of force distribution along the pile. The work was presented at the XVII French-Polish Colloquium of Soil and Rock Mechanics, Łódź, 28-30 November 2016.
\end{abstract}

Key words: foundation piles, static load test, pile instrumentation, strain gage, numerical analysis

\section{INTRODUCTION}

In geotechnical engineering, due to the nature of soil as a construction material, designers are never one hundred percent sure what they are dealing with. Soil, even with the same physical properties will behave differently in various conditions and under various types of load. Therefore, engineers usually try to verify the correctness of their design conducting more or less advanced field tests. One of such tests used for pile foundation is a pile load test. An ordinary bearing capacity test is usually carried out in order to determine the relationship between the load and displacement of the pile head. However, engineers may need more detailed information regarding soil behaviour and load distribution along the pile for a proper structure design, when piles can be longer or shorter or have a different size or to resolve a negative friction problem. In such a case an instrumented pile testing technology must be applied.

\section{Instrumented pile test}

The instrumented pile testing technology allows to determine load distribution along the pile, the amount of load carried by pile shaft resistance and by soil underneath the pile base [3]-[5], [7]. Generally, pile instrumentation consists of strain gages [15], where the measurement of strain and load values are recalculated from the change of strain by multiplying its value with the concrete modulus (pile material) and the cross sectional area. A relatively new technique is the use of fiber optic sensors [16], however, ideology is the same - strain measurement and stress calculation. Test results interpretation is not simple, it requires an extensive analysis and proper engineering judgment. There are many factors affecting the readings, however, not all engineers are fully aware of them. The main problems in the proper load distribution evaluation are:

- correct system installation,

- determination of the real concrete modulus value,

- pile core heterogeneity,

- residual internal forces.

Proper system set up is crucial for the whole testing procedure [9]. It may secretly affect the results and lead to a false conclusion. This is why it is extremely important to use a high quality equipment, high professionalism and pay attention to detail. An experienced evaluator should be able to detect any major errors and apply required corrections. The de- 
termination of the true values of concrete modulus and pile real diameter plays a significant role in the whole process of load distribution evaluation. The equation (1) explains the relationship between all these factors.

$$
P=\varepsilon \cdot E \cdot A
$$

where:

$P$ - axial load (force causing a given deformation) $[\mathrm{kN}]$,

$\varepsilon-$ axial strain of pile shaft $[-]$,

$E$ - concrete modulus $\left[\mathrm{kN} / \mathrm{m}^{2}\right]$,

$A-$ cross section area of pile shaft $\left[\mathrm{m}^{2}\right]$.

While estimating the deformation of a compressed concrete element, the concrete modulus inaccuracy (of $20-30 \%$ ) does not play a significant role, because in this case strain is relatively low and such an inaccuracy may cause only some tenths of millimeter difference. This is why in common design practice concrete is usually assumed to be a linear elastic - ideally plastic material and the standard value of the modulus can be taken from a national code or design manual [17]. However, in the real life scenario the load-deformation characteristics of concrete under compression are nonlinear and this nonlinearity has a significant influence on the interpretation of force distribution along a pile equipped with strain gages. It was proven before [3], [13], [17] that adapting a constant, standard concrete modulus value for investigation purposes may cause incorrect results in pile shaft friction and pile tip resistance.

Nowadays there are few methods that researchers use to determine the real concrete modulus value or at least its approximation. One of them is to place some strain gages located in a pile above the ground or remove soil around the pile to a certain depth - which is a preferred method due to more realistic conditions. When a part of the pile is not embedded in soil there is no skin friction and a full load applied to the pile head is transferred to the lower parts of this pile, which allows to measure strain and therefore determine the stress-strain characteristics of concrete. However, this method does have certain drawbacks. One is the fact that "end effects" gages installed close to the pile head can be affected by stress non-uniformity which occurs directly below the point of load application (hydraulic jack). In bored piles the cross section is rarely uniform along the pile and the dimensions can be assessed only roughly. What is more, the cost of placing extra gages might also be a factor while considering an investigation program [12].

The other method is the tangent stiffness procedure proposed by Fellenius [3] and detailed information can be found in his work. The method assumes that the pile top load increments and respective strains measured at various pile depths are known from the investigation. Stress-strain characteristics are plotted, all of them are curved. First of all, it is caused by the natural nonlinearity of the concrete stiffness and for the point below the ground level. The second reason is pile shaft friction. In a normal situation strains below the ground level are smaller those that measured at the pile head level. However, when the skin friction is fully mobilized the strain increment at a certain level below the ground is equal to the one above the ground level. As a result any load increment is fully reflected in the strain increment without any soil contribution.

In the present study the authors combined the first method with their own procedure of concrete modulus determination, where the stress-strain behavior is nonlinear, approximated by a power function. What is more, authors believe that concrete modulus values change also with depth, which is caused by the concrete weight itself, soil pressure and water absorption level. For this reason additional interpolation with depth was also applied. The procedure of concrete modulus determination is iterative. The details of the authors' approach have not been published yet.

Pile deformations may be of crucial significance for the determination of load distribution along the pile. Especially for piles formed in the ground (drilled, bored) it is difficult to define the real concrete stiffness value (EA). It is due to the possible nonhomogeneity of the pile modulus or diameter and might be caused by the presence of cohesive or noncohesive soil layers in the ground. Examples of such a non-homogeneity are presented in Fig. 1.

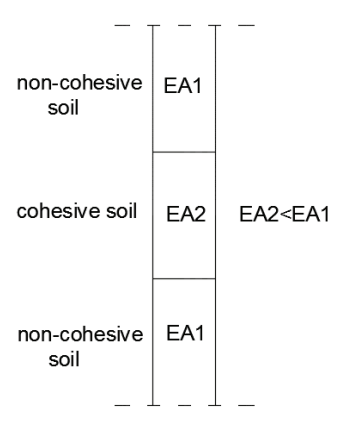

(a)

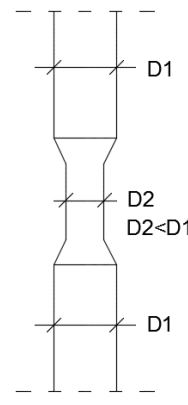

(b)

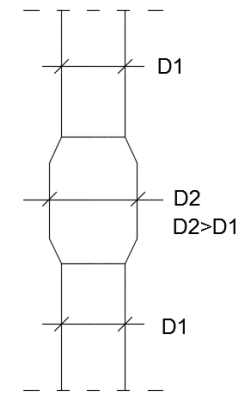

(c)
Fig. 1. Pile deformations: (a) lower stiffness value in one of the pile sections, (b) pile diameter local necking, (c) pile diameter local widening

At the beginning of the test, all readings are set to zero. However, before start of the loading test, initial force can exist in the pile and it can be large. Such a force is due to locked-in strain and is called residual force [5], [6]. The presence of this force may have 
various reasons. One of them can be the dead weight of the pile itself. However, this factor is natural and usually neglected in the analysis. The shrinkage of concrete might be considered as the second reason. While curing concrete changes its volume and some local forces become locked in the pile core. Third - negative friction in the upper parts of the pile. The fourth possible cause, in the case of precast piles, is pile driving itself as it puts additional stress into the pile. The main problems with the residual force encompass its preexistence before the pile instrumentation is installed and its variability along the pile length. Several researchers around the globe are currently working on an efficient method for residual force determination [18]. However, residual forces will not be discussed in this paper.

\section{STATIC LOAD TEST}

\section{Field investigation}

A static load test of an instrumented largediameter bored pile was chosen as an example for this investigation. The pile was installed at the Odra bridge construction site, which was a part of the Wrocław highway (bypass) project. Due to the importance of the project, it was decided to perform an instrumented pile load test. It is worth mentioning that this was one of the first strain gage method application for piles in Poland.

The investigated pile was $19.7 \mathrm{~m}$ long with $1.5 \mathrm{~m}$ diameter. It was drilled using a temporary casing. The
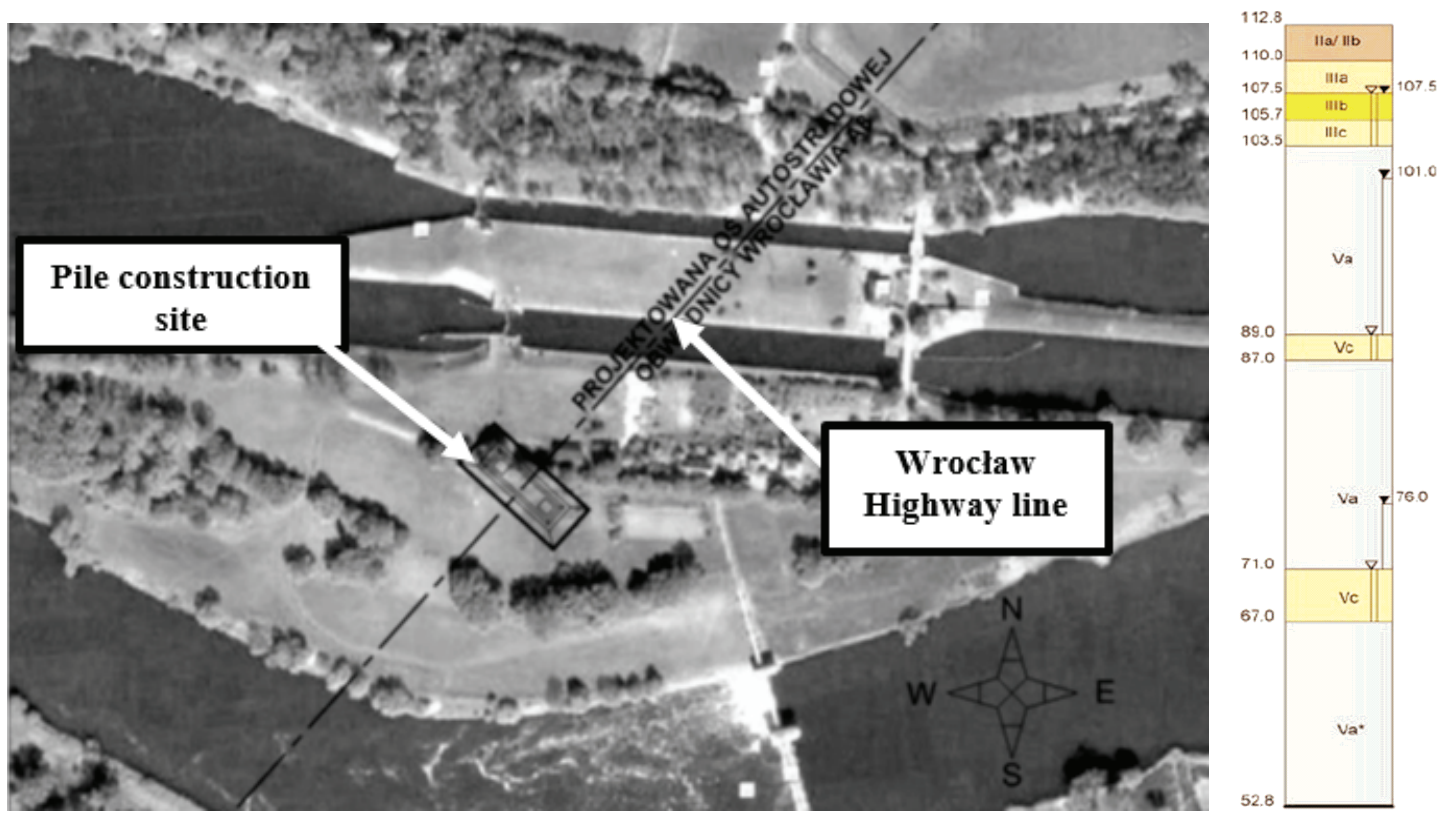

Fig. 2. Construction site and soil profile [2]

Table 1. Soil geotechnical parameters

\begin{tabular}{|c|c|c|c|c|c|c|}
\hline Soil layer & Soil type & $\begin{array}{c}\text { Unit weight } \gamma / \gamma^{\prime} \\
{\left[\mathrm{kN} / \mathrm{m}^{3}\right]}\end{array}$ & $\begin{array}{c}\text { Friction angle } \varphi^{\prime} \\
{\left[{ }^{\circ}\right]}\end{array}$ & $\begin{array}{c}\text { Cohesion } \\
c^{\prime}[\mathrm{kPa}]\end{array}$ & $\begin{array}{c}\text { Oedometric } \\
\text { modulus M0 } \\
{[\mathrm{kPa}]}\end{array}$ & $\begin{array}{c}\text { Poisson } \\
\text { ratio } v \\
{[-]}\end{array}$ \\
\hline $\mathrm{IIa} / \mathrm{IIb}$ & $\mathrm{Si}, \mathrm{sacISi}$ & $21.0 / 11.0$ & 15.0 & 5.0 & 30000 & 0.20 \\
\hline $\mathrm{IIIa}$ & Fsa, Msa, Csa & $19.0 / 10.0$ & 33.0 & 1.0 & 85000 & 0.20 \\
\hline $\mathrm{IIIb}$ & Fsa, Msa, Msa/clGr & $20.0 / 10.0$ & 35.0 & 1.0 & 150000 & 0.15 \\
\hline $\mathrm{IIIc}$ & $\mathrm{ClGr}, \mathrm{Gr}, \mathrm{Csa} / \mathrm{clGr}$ & $20.0 / 10.0$ & 35.0 & 1.0 & 220000 & 0.15 \\
\hline $\mathrm{Va}$ & $\mathrm{CI}, \mathrm{siCI}, \mathrm{sacISi}$ & $21.5 / 11.5$ & 23.0 & 18.0 & 40000 & 0.20 \\
\hline $\mathrm{Va}(\mathrm{deeper})$ & $\mathrm{Cl}, \mathrm{siCl}, \mathrm{sacISi}$ & $21.5 / 11.5$ & 23.0 & 18.0 & 100000 & 0.20 \\
\hline $\mathrm{Vc}$ & $\mathrm{SiSa}$ & $20.5 / 11.0$ & 32.0 & 1.0 & 85000 & 0.15 \\
\hline
\end{tabular}


construction site is presented in Fig. 2. and the geotechnical parameters are given in Table 1. More detailed information regarding soil condition, structure type and the used methods can be found in Dembicki et al. [2] and Krasiński and Sieńko [12].
In order to determine the real load distribution along the pile shaft, 7 strain gages where placed inside the pile core, which is shown in Fig. 3. Unfortunately due to some technological problems (improper installation) gages number 2 and 6 did not work properly.

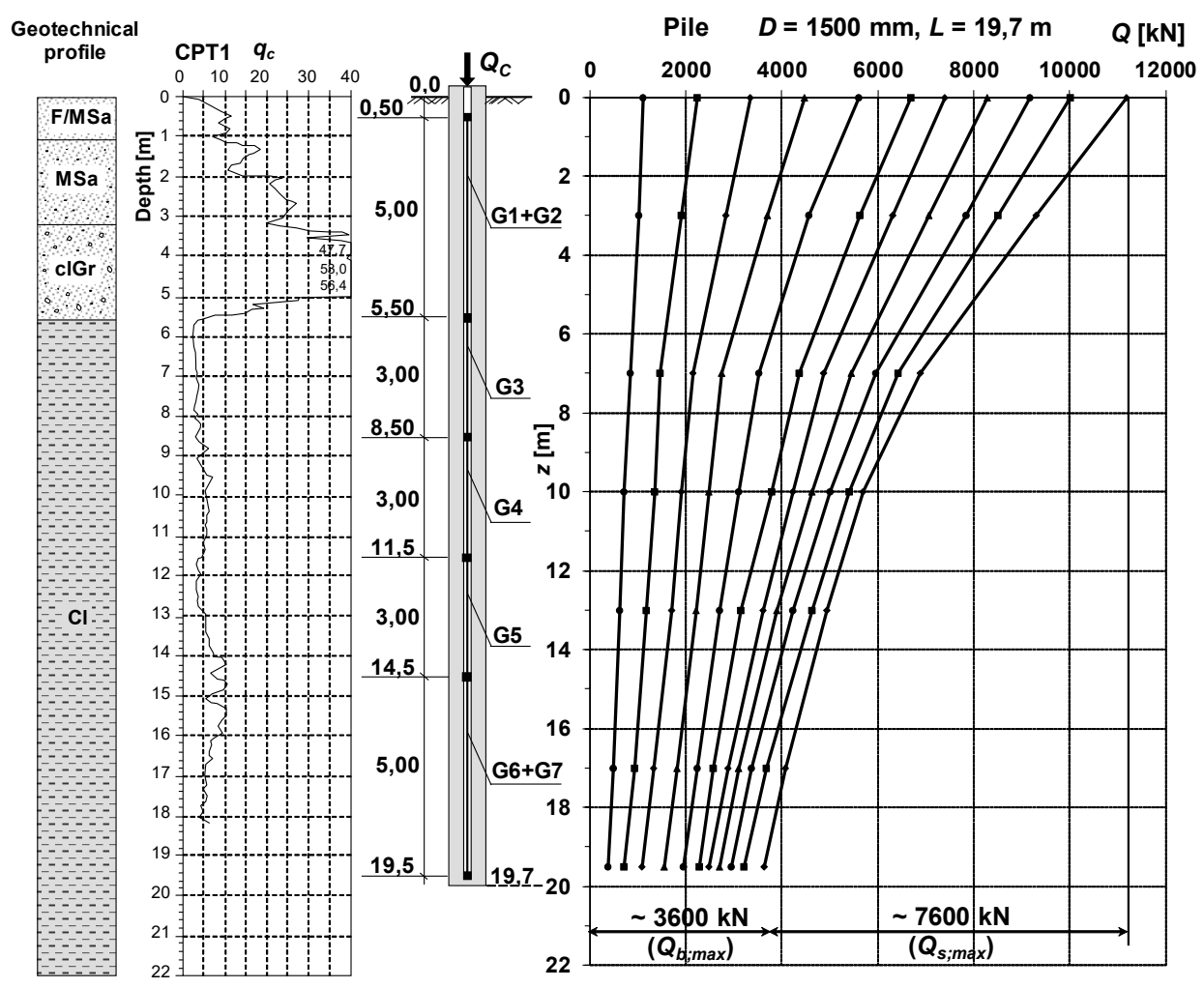

Fig. 3. Pile load distribution (G1-G5 - reading gages location)

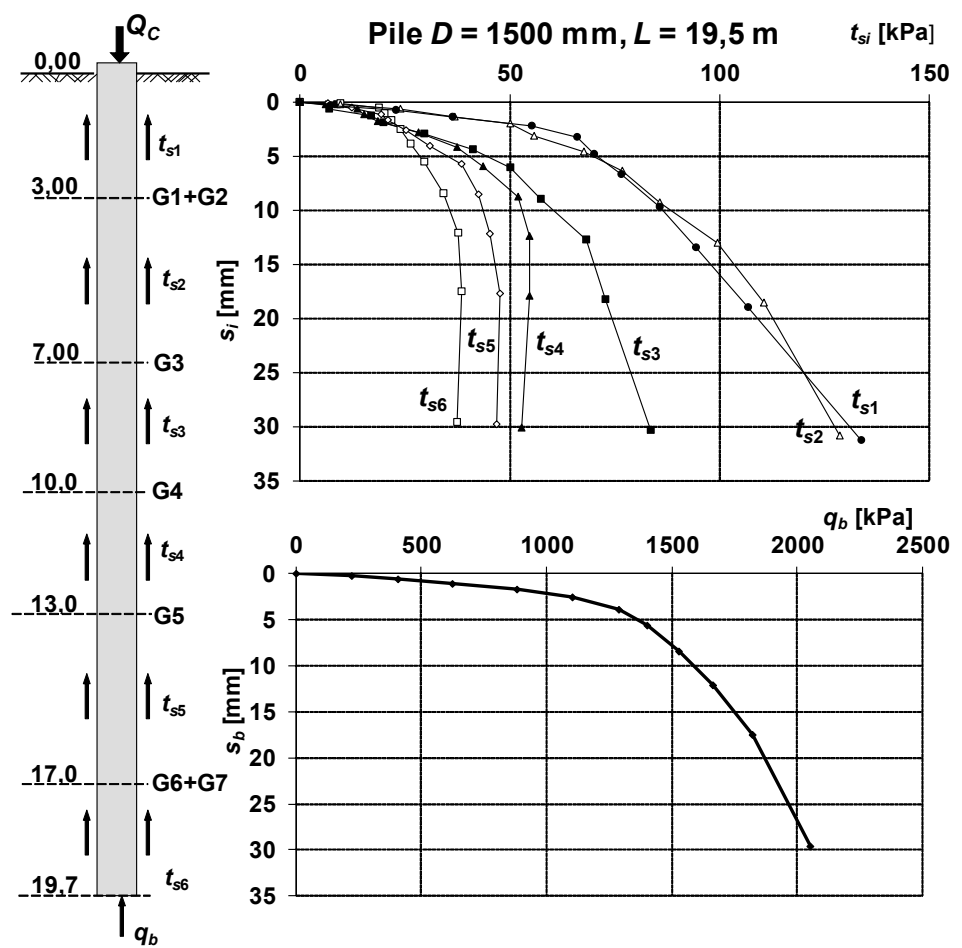

Fig. 4. Unit skin friction distribution $t_{s i}[\mathrm{kPa}]$ and unit load under the pile base $q_{b}[\mathrm{kPa}]$ 
Therefore, some modifications were made and displacement measurements in sections 1-2, 2-3 were taken as a sum into section 1-3, the same with sections 5-6, 6-7 summed into 5-7. It did not affect the general results, however, the force distribution chart divided into more sections may give more accrued readings. The Static Load Test standard procedures were followed and the maximum load of $Q_{\max }=11200 \mathrm{kN}$ was applied. The system setup and its functionally are widely covered in other previous publications [11]-[13].

\section{Static Load Test results}

After performing the test all data was reviewed and carefully analyzed. The final results are presented in the following figures. Load distribution along the pile is presented in Fig. 3, it shows that at $Q_{\max }$ shaft resistance is approximately equal to $7600 \mathrm{kN}$ and the soil resistance underneath the pile base is equal to about $3600 \mathrm{kN}$. A CPT graph is presented as well, it helps to analyze the results and explains higher skin friction in the first 5 meters of the pile, where sands and gravels were located.

Figure 4 presents skin friction distribution in particular sections related to section settlements (vertical displacement). It shows that skin friction was highest in the second and first sections. Pile head settled about $31 \mathrm{~mm}$, while the pile core shortening reached the value of about $2 \mathrm{~mm}$. Also the graph of pile base resistance against settlement was plotted.

All this information lets the investigator understand the soil-structure behavior. The knowledge of how this particular soil acts under particular stress allows engineers to adjust structure design, reduce or increase pile length or diameter. The applied testing and analyzing procedures seem to give reliable results.

\section{NUMERICAL SIMULATION}

In order to simulate field test results numerical analysis of the pile load test was carried out. There is only limited information in the literature regarding this kind of computer calculations of pile behavior in the soil. It is a complicated task to properly reconstruct all site conditions and correctly apply the construction and loading stages.

\section{Simulation methods}

For the numerical analysis a commercially available and popular in geotechnical engineering software was used. Plaxis 2D v. 8.6 is a Finite Element Method based program. Some suggestions related to the modelling process and authors' comments are presented in Krasiński [11], [14]. The properties of materials used in the analysis are shown in Table 2. For all four types of soil (Sand I as layer IIIa, Sand II as layer IIIb, Sand III as layer IIIc and Clay as layer Va) the Hardening Soil Model was used, it is a more advanced approach than the traditional Coulomb-Mohr model and its hyperbolic stress-strain relation better represents soil behavior. The soil model input parameters were simplified due to limited data from the investigation site. Stiffness modulus $E_{\text {oed }}^{\text {ref }}$ was taken as the modulus value

Table 2. Material properties used for numerical simulations in Plaxis

\begin{tabular}{|c|c|}
\hline Material & Properties \\
\hline Sand I & $\begin{array}{l}\text { Model HS, } \gamma=19 \mathrm{kN} / \mathrm{m}^{3}, \gamma_{s r}=19.5 \mathrm{kN} / \mathrm{m}^{3}, E_{50}^{\text {ref }}=95 \mathrm{MPa}, E_{\text {oed }}^{\text {ref }}=85 \mathrm{MPa}, E_{\mathrm{ur}}^{\text {ref }}=255 \mathrm{MPa} \text {, } \\
O C R=1, K_{0}=0.455, v_{\mathrm{ur}}=0.2, p^{\text {ref }}=100 \mathrm{kPa}, c=1 \mathrm{kPa}, \varphi=33^{\circ}, \psi=3^{\circ}, m=0.5, R_{f}=0.9\end{array}$ \\
\hline Sand II & $\begin{array}{l}\text { Model HS, } \gamma=20 \mathrm{kN} / \mathrm{m}^{3}, \gamma_{s r}=20.5 \mathrm{kN} / \mathrm{m}^{3}, E_{50}^{\text {ref }}=160 \mathrm{MPa}, E_{\text {oed }}^{\text {ref }}=150 \mathrm{MPa}, E_{\mathrm{ur}}^{\text {ref }}=450 \mathrm{MPa} \text {, } \\
O C R=1, K_{0}=0.426, v_{\mathrm{ur}}=0.2, p^{\text {ref }}=100 \mathrm{kPa}, c=1 \mathrm{kPa}, \varphi=35^{\circ}, \psi=5^{\circ}, m=0.5, R_{f}=0.9\end{array}$ \\
\hline Sand III & $\begin{array}{l}\text { Model HS, } \gamma=20 \mathrm{kN} / \mathrm{m}^{3}, \gamma_{s r}=20.5 \mathrm{kN} / \mathrm{m}^{3}, E_{50}^{\text {ref }}=230 \mathrm{MPa}, E_{\text {oed }}^{\text {ref }}=220 \mathrm{MPa}, E_{\text {ur }}^{\text {ref }}=500 \mathrm{MPa} \text {, } \\
O C R=1, K_{0}=0.426, v_{\text {ur }}=0.2, p^{\text {ref }}=100 \mathrm{kPa}, c=1 \mathrm{kPa}, \varphi=35^{\circ}, \psi=5^{\circ}, m=0.5, R_{f}=0.9\end{array}$ \\
\hline Clay & $\begin{array}{l}\text { Model HS, } \gamma=21.5 \mathrm{kN} / \mathrm{m}^{3}, \gamma_{s r}=20.5 \mathrm{kN} / \mathrm{m}^{3}, E_{50}^{\text {ref }}=50 \mathrm{MPa}, E_{\text {oed }}^{\text {ref }}=40 \mathrm{MPa}, E_{\mathrm{ur}}^{\text {ref }}=120 \mathrm{MPa} \text {, } \\
O C R=1, K_{0}=0.609, v_{\mathrm{ur}}=0.2, p^{\text {ref }}=100 \mathrm{kPa}, c=18 \mathrm{kPa}, \varphi=23^{\circ}, \psi=0^{\circ}, m=0.5, R_{f}=0.9\end{array}$ \\
\hline Concrete & Model Linear Elastic, $\gamma=25 \mathrm{kN} / \mathrm{m}^{3}, \gamma_{s r}=25 \mathrm{kN} / \mathrm{m}^{3}, E_{\mathrm{ref}}=45 \mathrm{GPa}, v=0.167$ \\
\hline
\end{tabular}

$H S$ - Hardening Soil, $\gamma$ - unit density, $\gamma_{s r}$ - effective unit density, $E_{50}^{\text {ref }}-$ stiffness modulus for primary loading in drained triaxial test, $E_{\text {oed }}^{\mathrm{ref}}-$ stiffness modulus for primary loading in oedometer test, $E_{\mathrm{ur}}^{\mathrm{ref}}-$ stiffness modulus for unloading/reloading in drained triaxial test, $O C R$ - overconsolidation ratio, $K_{0}$ - earth pressure coefficient at rest, $v_{\text {ur }}$ - Poisson's ratio for loading/unloading, $p^{\text {ref }}$ - Poisson's ratio for loading/unloading, $c$-effective cohesion at failure, $\varphi$ - effective friction angle at failure, $\psi$ - dilatancy angle at failure, $m$ - modulus exponent for stress dependency, $R_{f}$ - failure ratio. 
from the oedometer test. The reference value of modulus $E_{50}^{\text {ref }}$ for primary loading in a drained triaxial test was taken same (or similar) as $E_{\text {oed }}^{\text {ref }}$. The modulus for unloading/reloading $E_{\mathrm{ur}}^{\mathrm{ref}}$ was based on the oedometer modulus value multiplied by 3 (except for dense Sand III, where $E_{\text {ur }}^{\text {ref }}$ was assumed to be equal to $500 \mathrm{MPa}$ ). All layers were modeled as normally consolidated $(O C R=1)$, the earth pressure coefficient was set by default as $K_{0}=1-\sin \varphi$. Default settings were also applied to Poisson's ratio for loading/unloading $\left(\nu_{\mathrm{ur}}=0.2\right)$, modulus exponent for stress dependency $(m=0.5)$ and failure ratio $\left(R_{f}=0.9\right)$. Dilatancy angle $\psi$ was taken as $\varphi-30^{\circ}$. Concrete was modelled as a Linear Elastic material with modulus $E_{\text {ref }}$ equal to $45 \mathrm{GPa}$ (the reinforcement was taken into account). As stated before, it is a significant simplification and does not reflect the real concrete behavior. However, for the investigation purposes this inaccuracy is neglected. The results of such an attempt will be compared with real field data and then some conclusion will be made. In Fig. 5 the numerical modelling stages of pile installation and load test are illustrated.

In stage I, the pile was drilled in the soil, fresh concrete mix has some influence on the adjacent soil, which was introduced by additional pressure application (equal to concrete weight at particular depth). The value of this pressure was taken as hydrostatic pressure of the concrete.

In stage II, solid concrete material was assigned and soil-structure interface was activated. The stan- dard value of interface parameter $R_{\text {inter }}=0.9$ was adopted. In the last step, stage III, the pile loading process was modelled. Loading was divided into multiple phases, where the value increased from $0 \mathrm{kN}$ to $11200 \mathrm{kN}$ and was applied to the pile head. Because of relatively large deformations an updated mesh option was used in the calculation procedure. Some screen shots from Plaxis are shown in Fig. 6, (a) generated mesh, 4 areas with different densities can be seen. The next three graphs represent stress dissipation inside the pile core and in the soil around the pile, respectively: total displacement, vertical effective stress and relative shear stress. The test results are discussed in detail in the following section.

\section{Test results}

The numerical analysis was performed in order to compare the results with real (field) test data and to better understand the soil - structure (pile) interaction and also to improve the results interpretation of the pile load test. Load distribution along the modelled pile is shown in Fig. 7. It indicates that approximately $2100 \mathrm{kN}$ of the load was transferred to the pile base and carried by the soil underneath. Simultaneously a load of about $9100 \mathrm{kN}$ was borne by the soil adjacent to the pile, namely soil skin friction. It means that around $81 \%$ of total load was carried by the pile shaft and only $19 \%$ by the pile base. The results do not perfectly match the field test data, where $68 \%$ was carried by the pile shaft and $32 \%$ by the pile base. Therefore, the field data shows that friction along the
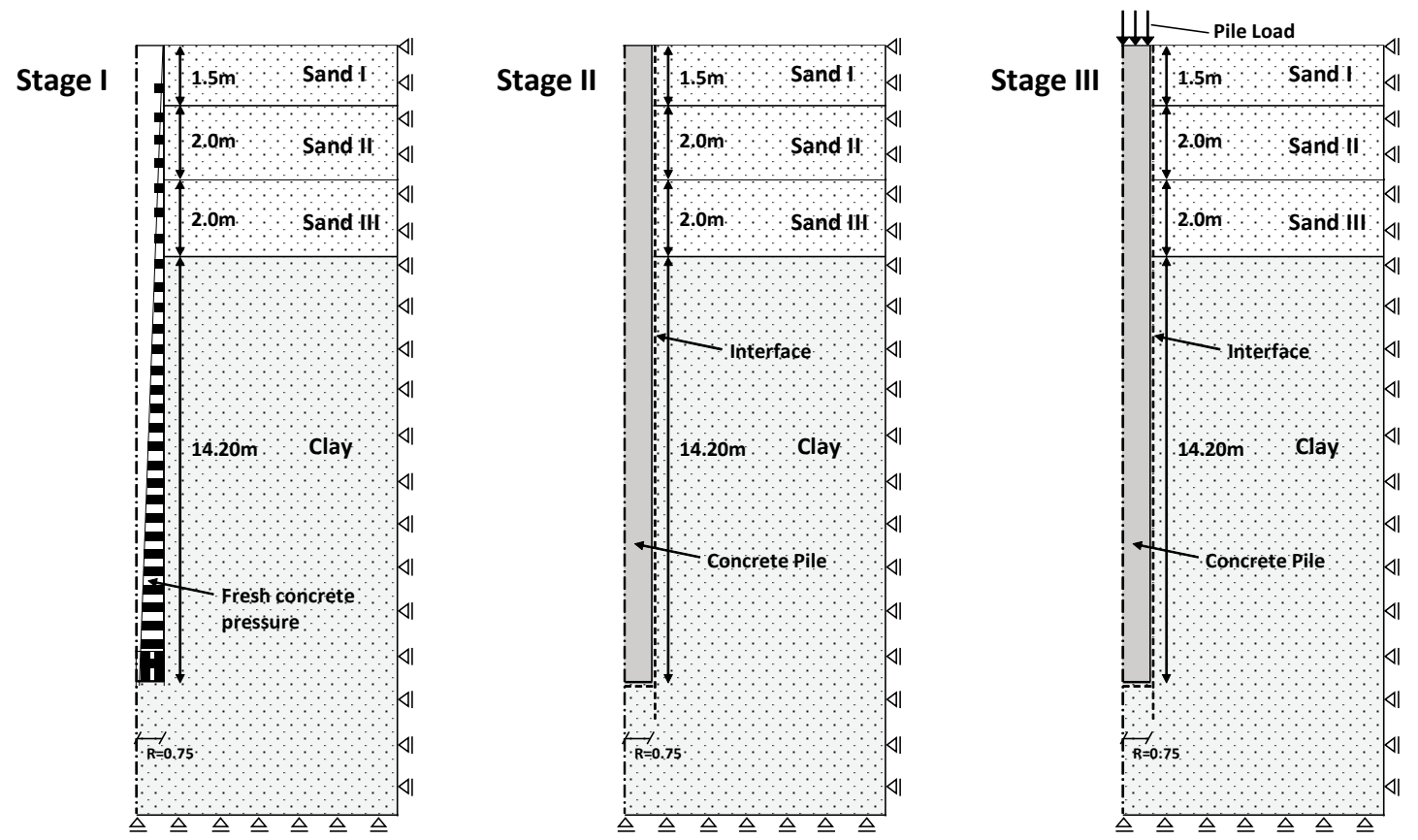

Fig. 5. Installation and load stages in numerical modelling of pile 
(a)
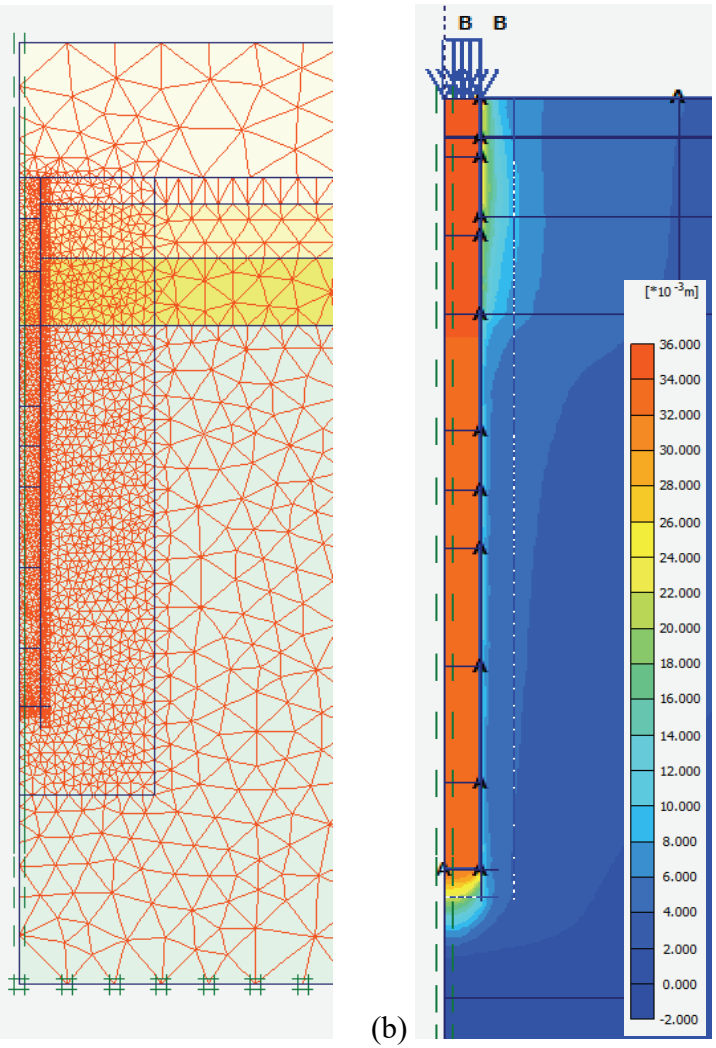

(c)

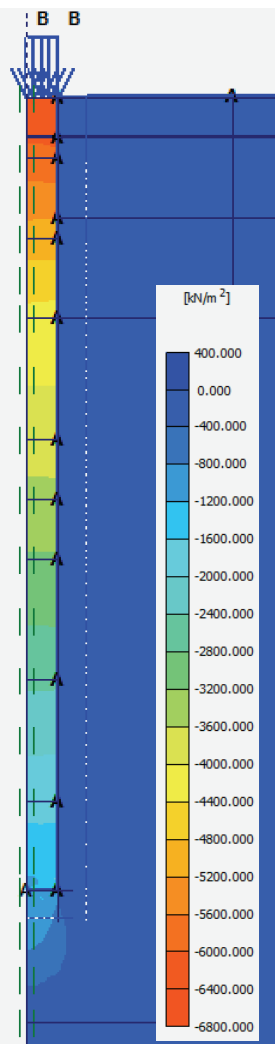

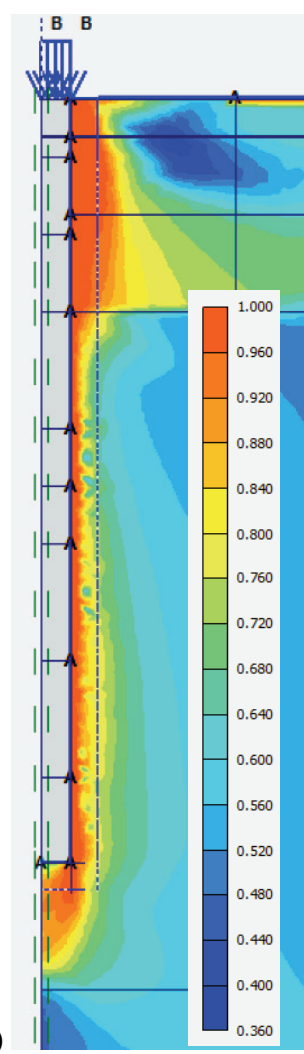

(d)

Fig. 6. Screens from Plaxis software: (a) generated mesh, (b) total displacement, (c) vertical effective stress, (d) relative shear stress

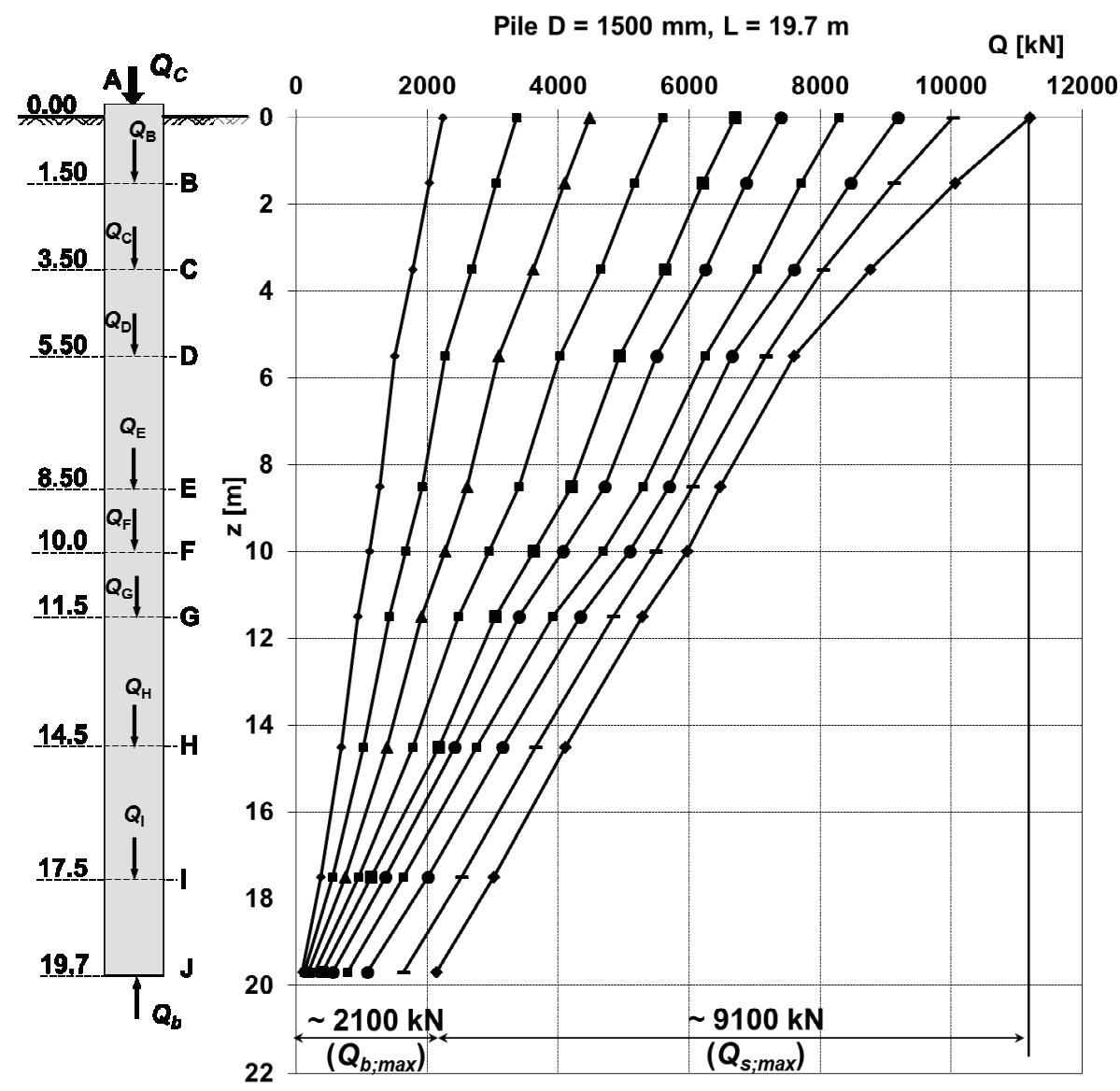

Fig. 7. Load distribution in a numerically modelled pile 


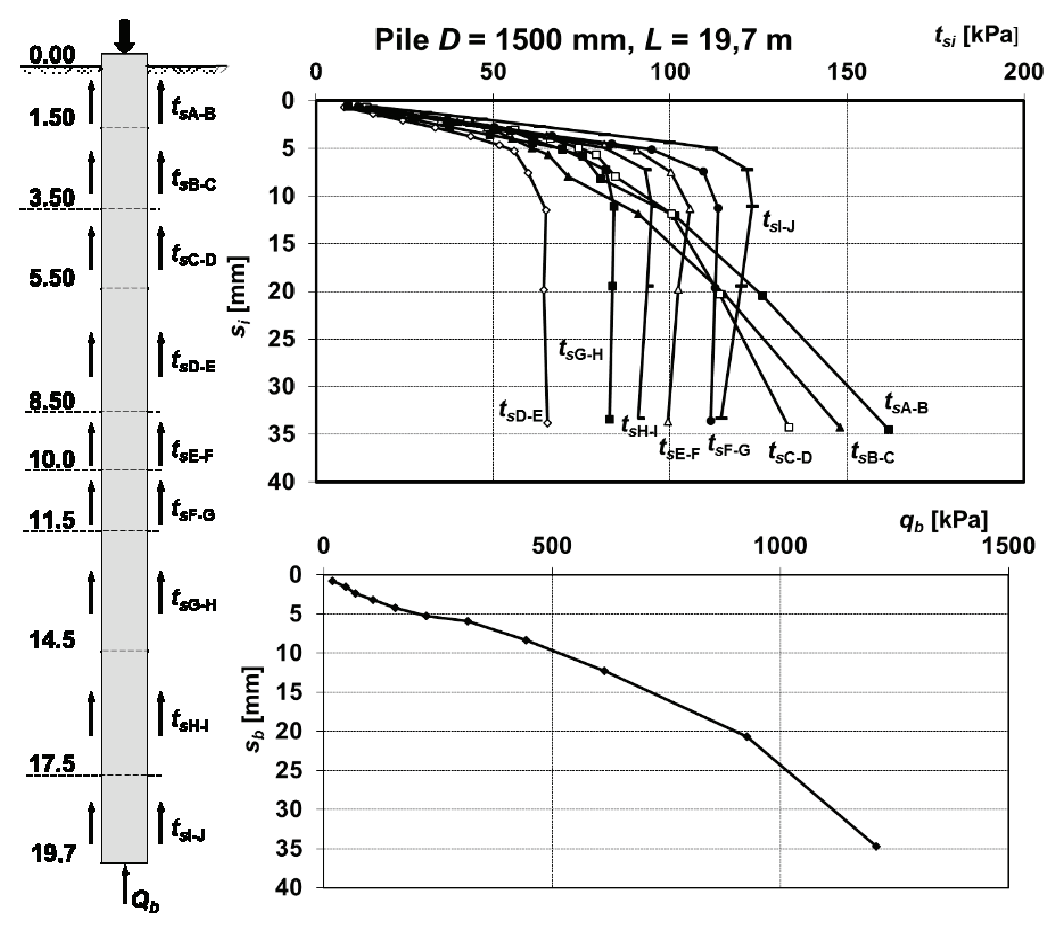

Fig. 8. Unit skin friction distribution $t_{s i}[\mathrm{kPa}]$ and unit load under the pile base $q_{b}[\mathrm{kPa}]$ derived from numerical analysis

pile had lower values than the friction derived from the numerical analysis, alike with the mobilized pile base resistance, lower resistance for the numerical analysis and higher for the field test. So the question is which results are true, which describe soil structure behavior more precisely. The authors believe that answer lies somewhere in between and both methods contain errors and inaccuracies. For example incorrect contact interface modelling may cause misleading skin friction values and therefore lower or, like in this case, higher pile shaft resistance. Soil model parameters that were significantly simplified are of great importance here.

Upper soil layers carried more load then the lower ones, it is represented by the slope in Fig. 8. That is because the upper sandy layers have higher skin friction than weaker clay layers, it is also shown in detail in Fig. 8, where unit soil resistances are presented. Pile head settlement was determined to be equal to $34.7 \mathrm{~mm}$, which is higher than the value determined from the field load test $(31 \mathrm{~mm})$. The difference is not significant and was most probably caused be the above mentioned reason.

\section{CONLUSIONS}

- To take full advantage of the static loading test and measure the load distribution, pile instrumentation is required.
- The paper demonstrates that the use of strain gage measuring method can provide significant advantages in pile load distribution analysis.

- Detailed pile load distribution might be helpful in the design of other nearby piles. The analysis may allow engineers to change pile geometry (e.g. shorten pile length and save money).

- In the case of construction failure, pile load distribution is extremely useful in order to determine reasons of such a failure and to prevent such events in the future.

- Concrete elastic modulus value must not be taken from a general code, its value should be determined at the investigation site.

- Concrete stress-strain behavior is not linear elasticperfectly plastic, but it was proven that stress-strain relation is more complicated and requires additional analysis to properly determine the modulus value.

- The numerical simulation was shown to be a useful tool in understanding soil-structure interaction. However, it requires further research and applications for a more precise analysis.

- There are several factors and processes, i.e., pile imperfections and residual loads in the pile load test procedure that are still not well understood and may have a significant influence on load distribution results. Neither of them was widely discussed in this paper, but they are already being studied and will be presented in the upcoming publications. 
- Numerical modelling software (e.g., Plaxis) reduces time and costs, increases efficiency and reliability when compared to standard field load tests on instrumented piles. It allows to perform numerous analyses for various soil conditions and pile types.

- Additionally, strain gage application helps to determine the cause of unfavorable static pile test results (if it is the reason for pile shaft or pile base resistance).

\section{REFERENCES}

[1] Bustamante M., Doix B., A new model of LPC removable extensometers, Proceedings of 4th Int. Conf. on Pilling and Deep Foundations, STRESA, Italy, April 7-12, 1991.

[2] Dembicki E., Cudny M., Krasiński A., ZALeski K., Pylon foundation of a cable stayed bridge at the motorway ring road of Wroctaw, 18th International Conference on Soil Mechanics and Geotechnical Engineering, Paris, September 2-6, 2013.

[3] Fellenius B.H., Tangent modulus of piles determined from strain data, The ASCE Geotechnical Engineering Division Foundation Congress, 1989, Vol. 1, 500-510.

[4] Fellenius B.H., Brusey W.G., PePe F., Soil setup, variable concrete modulus, and residual load for tapered instrumented piles in sand, ASCE Specialty Conf. on Performance Confirmation of Constructed Geotech. Facilities, University of Massachusetts, Amherst, USA, April 9-12, 2000.

[5] Fellenius B.H., Determining the resistance distribution in piles. Part 1: Notes on of no-load reading and residual load. Part 2: Method for determining the residual load, Geotechnical News Magazine. 2002, 20(2), 35-38 and 20(3) 25-29.

[6] Fellenius B.H., Determining the true distributions of load in instrumented piles, ASCE International Deep Foundation Congress, Orlando, Florida, 2002.
[7] Fellenius B.H., Unified design of piled foundations with emphasis on settlement, ASCE, Current Practice and Future Trends in Deep Foundations, GSP No. 125, Los Angeles, California, 2004, 253-275.

[8] Fellenius B.H., KIM S.R., ChUNG S.G., Long-term monitoring of strain in strain-gage instrumented piles, ASCE Journal of Geotechnical and Geoenvironmental Engineering, 2009, 135(11), 1583-1595.

[9] Fellenius B.H., ОсноA M., Testing and design of a piled foundation project. A case history, Geotechnical Engineering, Journal of the Southeast Asian Geotechnical Society, 2009, 40(3), 129-137.

[10] KIM S.R., ChUng S.G., FellenIUs B.H., Distribution of residual load and true shaft resistance for a driven instrumented test pile, Canadian Geotechnical Journal, 2011, (48)4, 583-598.

[11] KRASIŃSKi A., SieŃKo R., Pomiar pionowego rozkładu sity $w$ palu podczas testów statycznych, 56 Konferencja Naukowa Kielce-Krynica, 19-24.09.2010, (in Polish).

[12] KRASIŃSKI A., SIEŃKO R., Wykorzystanie pomiaru pionowego rozkładu sity $w$ palu do interpretacji testów statycznych, Magazyn Autostrady, 2010, 11, 24-28, (in Polish).

[13] KRASIŃSKI A., Wyniki badań terenowych pali i kolumn wkręcanych, Inżynieria Morska i Geotechnika, 2011, 6, (in Polish).

[14] KRASIŃSKI A., Numerical simulation of screw displacement pile interaction with non-cohesive soil, Archives of Civil and Mechanical Engineering, 2014, Vol. 14, No 1. 122-133.

[15] KRASIŃSKI A., KuSIO T., Pile model tests using strain gauge technology, Studia Geotechnica et Mechanica, 2015, 37(3), 49-52.

[16] LiU B., ZHANG D., XI P., Mechanical behaviors of SD and CFA piles using BOTDA-based fiber optic sensor system: A comparative field test study, Measurement, July 2017, Vol. 104, 253-262. DOI: 10.1016/j.measurement.2017.03.038.

[17] SaHAJDA, K., Discussion to the paper of A. Krasinski: "The results of field tests on screw piles and columns", Inżynieria Morska i Geotechnika, 2012, Vol. 33, No. 2, 114-118 (in Polish).

[18] Siegel T.C., Mcgillivray A., Interpreted residual load in an augered cast-in-place pile, 34th Annual Conference on Deep Foundations, Deep Foundations Institute, 2009, 173-182. 